\title{
Partnership Strategies: Pro-active and Pre-active Approach in Conflict Management in International Joint Ventures
}

\author{
Huu Le Nguyen \\ Hanken School of Economics \\ Kauppapuistikko 2, PO Box 287, 65101 Vaasa, Finland \\ E-mail: lnguyen@hanken.fi
}

Received: February 17, $2011 \quad$ Accepted: April 7, 2011 doi:10.5539/ijbm.v6n9p38

\begin{abstract}
Due to the differences in national and organizational cultures, and in motives of entering partnership conflicts between partners in international joint ventures (IJVs) often arise. Failure to handle conflicts often leads to termination of the IJVs. This paper builds up comprehensive model for handling conflicts between partners in both approaches: proactive and reactive approaches. The paper concludes with offering implications for both managers and opportunities for further studies.
\end{abstract}

Keywords: Joint ventures, Conflict, Proactive and Pre-active approach

\section{Introduction}

As firms are increasing their business activities abroad, they often involve in international joint ventures (IJVs) with local firms (Dunning, 1995; Dinh 1997; Li, 2003; Duan, 2007; Meschi \& Riccio, 2008). However, earlier research on IJVs shows a high rate of IJV failure (Hennart et al. 1998, Bamford et al., 2004; Yeheskel et al., 2004). Because firms have different goals, ways of operations, inter-partner conflicts often exist (Fey \& Beamish, 1999). Thus, understanding conflict management is crucial to organizations (Boonsathorn, 2007; Das \& Kumar, 2010; Ho, Joseph, \& Alan, 2010) as it influences IJV performance (Fey \& Bearmish, 1999; Lu, 2006; Yavas, et al., 1994). Similarly, Wang et al. (2005) maintain that understanding the way in which people from different cultures resolve conflict is very important. Researchers suggest that foreign parent firms differ in their choice of conflict resolution strategies (Wade-Benzoni et al., 2002). However, conflict resolution strategy is under-explored area in international business and management literature (White III et al., 2007; Speakman \& Ryals, 2010). Wang et al. (2005) notice that conflict handling styles have been given attention in IJV research. Zhenzhong et al. (2008) and Doucet et al. (2009) suggest further studies are needed to investigate conflict management style. Jehn and Weldon (1997) maintain that there has been lacking of systematic study on conflict management.

This paper aims to establish a model for managing conflicts between partners in IJVs in two ways: 1) before conflict happen: prevent conflicts to occur (proactive approach) and 2) dealing with actual conflict: curing/treatment of conflicts (reactive approach).

Previous studies, when discussing about conflict resolution strategies, have focused on only one factor (e.g. Ding, 1996; Lin \& Germain, 1998; Doucet, 2009) and at the general level. This study aims to contribute to research tradition in both IJV research and conflict management theory by specifying how partners can prevent potential conflicts from early joint venture establishment. This study differs from previous studies a number of ways. First, most previous studies on managing conflicts in IJVs have ignored to analyze how firms can prevent conflicts to happen. Second, this paper different from previous research in the way that it builds up the model of conflict management strategies in more detail by showing different steps, different conflict management strategies and their applications. In additions, this study extends previous research on conflict management in IJVs by also pointing out the important of follow-up period of conflict resolution and showing how firms can achieve this important step.

\section{Literature review and model development}

Conflict is often regarded as a negative force, harmful element (Boonsathorn, 2007) leading to discomfort, misunderstanding, and disruption of relationships or even collapse of organizations (Robbins, 2005). Fey and Beamish (1999) argue that conflict must be dealt with because it is inherent in relationship. Thus, it is important to know how to manage conflict in partnership.

After carefully gone through different leading journals in the field of international business and international management like Journal of International Business Studies, Journal of International Management, International 
Business Review, Management International Review, International Journal of Conflict Management, Journal of International Marketing, Academy of Management Review, we identify the key points of previous studies as followed. Most previous studies either focus on analyzing conflict management style of single country (e.g. Ding, 1996; Fey \& Beamish, 1999) or comparing that of two countries (e.g. Doucet et al., 2009; Boonsathorn, 2007; Yavas et al., 1994) or some countries (e.g. Kim et al., 2007; Lu, 2007; Onishi \& Bliss, 2006; Peng et al. 2000) or between Western style and Asian style (Wang et al, 2005; Peng, 2000) or using one single cultural dimension to analyzing the preference for conflict management strategy (e.g. Komarraju et al., 2008). Besides, previous studies also focus on providing strategies to avoid conflict (e.g White III et al, 2007; Barden, 2005) in general or the effect of cultural similarity, age of relationship, and general relative power of partners (e.g. Lin \& Beamish, 1999) on preference of conflict resolution strategies. This study attempts to provide fuller knowledge of how firms can management conflicts in IJVs. In addition, the model of conflict management in this study can be used for firms from different countries and operating in different industries. Next, we discuss in detail how conflicts in IJVs can be managed by using proactive approach and reactive approach.

\subsection{Proactive approach}

\subsubsection{Selecting partner fit}

In particular, conflicts between partners are caused by the differences between partners such as the incompatible management styles and approaches, and cultures (Killing, 1983). Differences between partners often increase the risk of misunderstanding and cooperation failures (Child \& Yan, 2003). Conflict may occur because partners pursue different goals, having different strategies, different organizational and national cultures. Partner fit is very important for cooperation and operations of IJVs (Buckley \& Casson, 1988; Yan \& Duan, 2003). Selecting suitable partners will help members get along and create positive synergies in IJVs and minimize negative atmospheres which are often cause conflict within partner relation. According to Geringer (1988), for IJV operate better, partner selection need to be emphasized on the fit of both in task-related characteristics and partner-related characteristics. In task-related sides firms mostly look for partners in comparable or complementary of resources and skills. In partner-related sides, firms may look for their partners with similar sizes, objectives, management styles. According to Das and Teng (1999) and Luo (1998) partner fit should be considered in partner selection and it includes strategic fit, organizational fit, and cultural fit. Fey and Beamish (1998) argue that conflicts in IJVs often occur if partners have incongruity objectives in IJVs. The differences in goals and objectives in IJVs are also one of the reasons of increasing the possibility of IJV termination (Hennart et al., 1998). In addition, Killing (1983) maintains that partners with extremely size differences will have problems with mismatches in strategic mission, corporate culture, and level of bureaucracy. Lu (2006) argues that partner differences in management styles lead to conflict in IJVs. In short, it is crucial for firms planning to enter IJV relationship to seriously consider partner fit to reduce conflicts which may occur later.

\subsubsection{Partnership negotiation}

IJV control. Previous research has noted that IJV control is also a source of conflict between partners (Barden et al. 2005, Ding, 1997). In IJV negotiation for IJV control, a partner can take one of positions including: dominant control, share control, minor control, and split control. Dominant control of IJV by one partner may also be a source of IJV conflicts since in this type of IJV, one partner may dominate all major decisions of its IJV activities and leaves too little room for the other to say. This type of control sometime lead to faster decision making process for IJVs, however, it is often found that most cases of conflicts between partners happened in dominated IJVs by foreign firms (Barden et al., 2005). On the other hand, share control or split control help to reduce conflict between partners since it both partners are involve in IJV decision making as it fosters environment of fairness, respect, and mutual trust (Barden et al., 2005). It is even better for reducing IJV conflict when each partners control their own expertise in cases of split control (Kauser, 2007).

IJV performance measurement is a key influence to partner relationship as it reflects how partners have been effectively working together. Thus, choosing right performance measures to evaluate IJV performance are very crucial (Geringer \& Herbert, 1991; Nguyen \& Larimo, 2010). Wrong choice of performance measures or disagreement between partners on how to evaluate IJV performance often causes conflicts between partners in terms of profit sharing, and subsequent activities in IJV operations.

IJV profit sharing is also crucial issue that may keep IJV harmony or conflicts between partners. If partners have perceptions of unfairness in IJV profit sharing, they may lose their motivation in partnership and it may cause conflict and negative affect to IJV performance. According to (Barden et. Al, 2005) partners will expect the outcomes of IJVs to be distributed in proportion to partners' contributions. Luo (2009) mentions that distribute justice is a foundation for cooperation between firms. Failing comply with this principal often results in mistrust, or even conflicts or even termination of joint ventures (Johnson et al. 2002). This is because unfairly distributed profit leads to dissatisfaction, reduced commitment of suffering partners.

\subsubsection{Building relational quality}

The nature of relationship between firms often plays key role in cooperation and conflicts in IJVs. Thus, it is important for firms to increase their relationship quality with their partners in IJVs by increase the level of 
communications, the level of trust and commitment with the other partners in IJVs. Trust is mentioned in international literature as a critical factor affect relational quality (Das \& Teng, 1998; Madhok, 2006). High level of trust between partners often means high level of knowledge exchange and better level of commitment of continue supporting IJV operations from partners (Wilson \& Brennan, 2009). It is noticed that high level of trust between partners will have positive effect to eliminate conflicts and also make conflict more easily to resolve. Commitment from partners is essential for IJVs longevity (Das \& Teng, 1998). Committed partners often consider long term gains rather than short term benefits. They tend to keep good relationship with partners and thus try to limit the influence of differences on causing of conflicts (Ozorhon et al., 2008; Ross, 2009).

Communication is important element for partners to understand role, operation of IJVs, and their responsibilities. Partners can avoid a lot of problems in running IJVs with open and effective communication (Cummings, 1984). Ross (2009) confirmed the role of communication in large scale projects to prevent conflict. On the other hand, failure in communication often results in misunderstanding, suspicion, conflicts and even termination of IJVs (Shenkar \& Zeira, 1992). Conflict resolution is necessary to be formalized in advance. In addition, when conflict occurs between partners, it is much more difficult to resolve it without formal standard procedure (Fey \& Beamish, 1999). Thuy and Quang (2005) argue that partners may have goals and interests that conflict with one another, so they must have a share intent to decide how to common solution. Through formal procedure, partners have clear picture of what problem is. This also helps to prevent the same type of conflict to happen again in the future.

\subsection{Reactive approach}

As firms follow proactive approach certain conflicts will be reduced. However, conflicts are part of any organization and especially of hybrid organizations like IJVs, it is important for partners to know how to cope with them when they do occur. To deal with conflicts, there are certain techniques and strategies that partners can use. Perhaps, most famous ones are technique suggested by Borisoff and Victor (1998) and strategy by Thomas (1976).

\subsubsection{Conflict handling steps}

Researchers suggest five steps of dealing with conflicts: assessment, acknowledgement, attitude, action, and analysis (Borisoff \& Victor, 1998). When conflicts occur, the first step that partners need to do is to assess the situation. In this step, partners need to collect information regard to whether there is really a conflict, and if so, how serious the conflict is, what the issue is, and what wishes and requests from the partners in IJVs are. As international joint ventures are involving with partners from different cultures, partner from different cultures may understand thing, body languages differently. Such cultural differences may be the reason leading to conflicts between partners (Holstede, 2001).

After getting enough information about the conflict, partners may need to acknowledge about the situation. In this step, partners will listen to the other partners' point of view. This allows partners to find out the main cause of conflict and to collect additional information for conflict resolution strategy decision later on. This will also show that the other partners' point of views is respected and confirmed, leading to openness of problem solving discussion from partners from two sides. The next step of conflict handling is to change possible attitudes which contribute to flame the conflict between partners such as stereotypical assumptions, differences in culturally-based behaviors, in the way of partners' communication, and non-verbal languages. The following step of conflict handling is to take action by choosing strategy to exercise to solve conflict. Then, partners need to analyze the result of strategy and what have been achieved.

\subsubsection{Conflict handling strategies}

There are different strategies that firms can apply to handle conflicts such as confronting, ignoring, avoiding, compromising, accommodating, and problem solving or going through a mediator (Thomas, 1976; Putnam \& Wilson 1982; and Rahim, 1983). Fundamental for conflict management style is based on concern for the benefits of oneself and/or concern benefits for other. Based on two dimensions including assertiveness (to satisfy one's own concern) and cooperativeness (to satisfy the concern of the other), Thomas (1976) constructs five conflict handling strategies: competing, collaboration, compromising, accommodating, avoiding. According to Rahim and Bonoma (1979), conflict management strategies include dominating, obliging, avoiding, compromising, and integrating. In this study, conflict resolution strategies include: problem solving, compromising, forcing, legalistic, avoiding, and accommodating strategy.

With problem solving strategy partners aim to satisfy the need from all parties involved. Exercising this strategy partners attempt to provide new effective solutions that will increase stakes for all parties involved. This strategy is suitable when the problem is complex. However, this strategy demands effort from both sides and it will take much longer time to use. With compromising strategy partners aim to achieve a common solution for both sides. They can do that by offering some concessions. This strategy can be used when both partners have equal bargaining power, perceiving the same important role of the relationship, or they need quick solution. Exercising forcing strategy, partners aim to dominate decision making. This strategy may be used when the problem is crucial for partners so that they will try to solve it in the way that can keep them safe by offering their own solution. Legalistic strategy may be used to solve conflict through advanced agreement. This often involves 
lawyers and very costly. In avoiding strategy, partners try to not directly deal with the problems. In this strategy, the issue is often very complicated and partners have a litter chance to win thus they may be not so willing to find the solution yet. By using accommodating strategy, partners will play according to the other partners' terms in resolve the problem. Partners use this strategy to increase the other partner cooperative behaviors as they perceive the relationship is much more important than the dispute itself.

\section{Insert Table 1 here}

In some cases, partners may predominantly use compromise strategy in conflict situations. Although there are different ways to handle conflicts, such partner is more likely to compromise than they are to force, problem solving, or legalize. This is due to the fact that each strategy will have its advantages and disadvantages. Below is the discussion of application of each strategy. When partners find themselves in conflict over very important issues, they may try to solve problem with their partners. Lin and Germain (1998) mention that when IJV partners try to dominate the conflict handling process, the other partner may become frustrated, leading to reduce the chance of solving the conflict and at the same time bring more possible of future conflict. In addition, it may be more effective for managers to concentrate on only areas in which conflict or disagreement arises (Ding, 1997). In the same vein, Kauser (2007) argues that partners should be encouraged to joint problem solving and this will permit a mutual solution to be reached and thereby improve IJV performance. However, when facing time pressure to resolve problem quickly, and if partners have dominant power in IJVs they may impose their solutions to other partners using forcing strategy. The efforts to resolve conflict by partners may become the most serious sources of conflict (Wang et al. 2005). Researchers suggest that with appropriate management approach, certain level of conflict may be turned into a positive force in organization practice (Daroczi, 2003). In short, to be successful in international joint venture relationship, partners should be able to use the appropriate conflict management strategy for each situation.

\subsubsection{Post conflict follow-up}

After conflicts have been resolved, it is important to monitor both the short-term and long-term effects of the conflict resolution. In addition, it is important to have follow-up period to make sure that everything get back as normal and erase negative feeling and attitudes towards each other since conflict handling is not a static procedure but it is rather a process (Borisoff \& Victor, 1998). Mechanisms for follow-up are evaluating partner actions, behaviors, and performance against what have been agreed upon during the resolution process. Especially, if partners use forcing strategy to solve conflict situation, the other partners may feel that their concerns did not get adequate consideration. In addition, social exchange and personal relationships may help to regain trust and neutral negative energies of the ventures. This can also be achieved by improving communication and continuously evaluation situation of the IJV operation (Borisoff \& Victor, 1998). It is also important to reaffirm commitment of partners into IJVs and long-term goal for IJVs.

\section{Conclusions}

Conflicts are parts of life and may appear in any organization. They particularly often occur in hybrid organizations whose parents coming from different cultures, different countries with different ways of thinking and doing things. Knowing how to management conflict with proactive approach (minimize conflicts to happen) and reactive approach (resolve conflicts) is crucial for firms to be successful in joint venture relationship. This paper benefits for both managers and researchers. For researchers, it offers testable model of conflict management (Figure 1.). For managers, the paper can be used as a guideline for firms to deal with conflicts in international joint venture relationship by following steps in the model.

As many other research papers, this paper has its own limitations. First of all, this paper is only a theoretical discussion and thus further study can use empirical data to confirm the validity and generalization of the model. Furthermore, here conflicts are assumed to happen in two parties-IJVs. Even though most parts of the model can be applied for multiple party-IJVs, the model may not hold true for more than two party-IJVs. Therefore, further study can use two parties-IJVs and multi-parties-IJVs to test the model. In addition, as the model points out conflict management approach from pre-formation to post-formation of IJVs, longitudinal study is of interest to capture the whole process of conflict management process in IJVs.

\section{Insert Figure 1 here}

\section{References}

Arino, A. (1997). Veracity and Commitment: Cooperative behavior in first time collaborative ventures. In Cooperative Strategies: European Perspectives. Edited by Beamish, P. W. and Killing, J. P. The New Lexington Press, San Francisco.

Bamford, J., Ernst, D., and Gubini, D. G. (2004). Launching a world class joint venture. Harvard Business Review, 82 (2), 91-100.

Barden, Q. J., Steensma, H. K., and Lyles, M. A. (2005). The influence of parent control structure on parent conflict in Vietnamese international joint ventures: an organizational justice-based contingency approach. Journal of International Business Studies, 36, 156-174. doi:10.1057/palgrave.jibs.8400121, 
http://dx.doi.org/10.1057/palgrave.jibs.8400121

Beamish, P. W., and Banks, J. C. (1987). Equity joint ventures and the theory of multinational enterprise, Journal of International Business Studies, 18 (1), 1-16. doi:10.1057/palgrave.jibs.8490403, http://dx.doi.org/10.1057/palgrave.jibs.8490403

Boonsathorn, W. (2007). Understanding conflict management styles of Thais and Americans in multinational corporations in Thailand. International Journal of Conflict Management, 18 (2), 196-221. doi:10.1108/10444060710825972, http://dx.doi.org/10.1108/10444060710825972

Brouthers K D, \& Bamossy G J. (2006). Post-Formation Processes in Easter and Western European Joint Venture. Journal of Management Studies, 43 (2), 203-229. doi:10.1111/j.1467-6486.2006.00588.x, http://dx.doi.org/10.1111/j.1467-6486.2006.00588.x

Buckley, P. J., and Casson, M. (1988). A theory of cooperation in international business. Cooperative strategies in international business, F. J. Contractor and P. Lorange, eds. Lexington Books, Lexington.

Cummings, T. (1984). Transorganizational development. Organizational Behavior, 6, 367-422.

Das, T. K., \& Kumar, R. (2010). Interpartner sensemaking in strategic alliances: Managing cultural differences and internal tensions. Management Decision, 48 (1), 17-36. doi:10.1108/00251741011014436, http://dx.doi.org/10.1108/00251741011014436

Das, T. K., \& Teng, B.-S. (1998). Between trust and control: developing confidence in partner cooperation in alliances. Academy Management Review, 23 (3), 491-512.

Das, T. K., \& Teng, B.-S. (1999). Managing risks in strategic alliances. Academy of Management Executive, 13 (4), 50-62. doi:10.5465/AME.1999.2570554, http://dx.doi.org/10.5465/AME.1999.2570554

De Dreu, C. K., and Weingart, L. R. (2003). Task versus Relationship Conflict, Team Performance, and Team Member Satisfaction: A Meta-Analysis. Journal of Applied Psychology, vol. 88, no. 43, pp. 741-749. doi:10.1037/0021-9010.88.4.741, http://dx.doi.org/10.1037/0021-9010.88.4.741

Ding, D. Z. (1996). Exploring Chinese conflict management styles in joint ventures in the People's Republic of China. Management Research News, 19 (9), 43-53. doi:10.1108/eb028491, http://dx.doi.org/10.1108/eb028491

Doucet, L., Jehn, K. A., Weldon, E., Chen, X., and Wang, Z. (2009). Cross-cultural differences in conflict management: An inductive study of Chinese and American managers. International Journal of Conflict Management, 30 (4), 355-376. doi:10.1108/10444060910991066, http://dx.doi.org/10.1108/10444060910991066

Duan J, \& Chuanmin S. (2007). Ownership, control, and performance of U.S.-China joint ventures: A longitudinal study. Journal of Applied Management and Entrepreneurship, 12 (1) 25-35.

Fey, C. F., and Beamish, P. W. (1999). Strategies for Managing Russian International Joint Venture Conflict. European Management Journal, 17 (1), 99-106. doi:10.1016/S0263-2373(98)00067-X, http://dx.doi.org/10.1016/S0263-2373(98)00067-X

Fey, C. F., and Beamish, P. W. (2000). Joint venture conflict: case of Russian international joint ventures. International Business Review, 9, 139-162. doi:10.1016/S0969-5931(99)00034-7, http://dx.doi.org/10.1016/S0969-5931(99)00034-7

Geringer, J. M. (1988). Joint venture partner selection: strategies for developing countries. Quorum, New York. Geringer, J. M., and Herbert, L. (1991). Measuring performance of international joint ventures, Journal of International Business Studies, 22 (2), 249-263. doi:10.1057/palgrave.jibs.8490302, http://dx.doi.org/10.1057/palgrave.jibs.8490302

Ghauri, P. N. (2003). Introduction. In P.N. Ghauri abd J-C Usunier (eds.), International Business Negotiation $\left(2^{\text {nd }}\right.$ ed). Oxford: Pergamon, 3-20.

Hennart, J. F., Kim, D. J., and Zeng, M. (1998). The impact of joint venture status on the longevity of Japanese stakes in U.S. manufacturing affiliates. Organizational Science, 9 (3), 382-395. doi:10.1287/orsc.9.3.382, http://dx.doi.org/10.1287/orsc.9.3.382

Hennart, J.F., and Larimo, J. (1998). The Impact of Culture on the Strategy of Multinational Enterprises: Does National Origin Affect Ownership Decisions by Foreign Direct Investors into the United States. Journal of International Business Studies, 29, 3, 515-538. doi:10.1057/palgrave.jibs.8490005, http://dx.doi.org/10.1057/palgrave.jibs.8490005

Ho, T. Y., Joseph, L, \& Alan, J. D. (2010). An empirical investigation of relational conflicts in co-marketing alliances. Journal of Business to Business Marketing 17, 249-278. doi:10.1080/10517120903465350, http://dx.doi.org/10.1080/10517120903465350

Hofstede, G. (1980). Culture's consequence: International differences in work related values. Beverly Hills, CA: Sage.

Hofstede, G. (2001). Culture's consequences: comparing values, behaviors, institutions and organizations 
across nations. $2^{\text {nd }}$ Edition. California: Sage Publications.

Jehn, K., and Weldon, E. (1997). Managerial attitudes toward conflict: Cross-cultural differences in resolution styles. Journal of International Management, 3 (4), 291-321.

John, J. P., Korgaard, M. A., Sapienza, H. J. (2002). Perceived fairness, decision control and commitment in international joint venture management teams. Strategic Management Journal, 23, 1141-1160. doi:10.1002/smj.277, http://dx.doi.org/10.1002/smj.277

Killing J. P. (1983). Strategies for joint ventures success. Praeger Publishers, New York.

Kim, T. Y., Wang, C., Kondo, M., and Kim, T. H. (2007). Conflict management styles: the differences among the Chinese, Japanese and Koreans. International Journal of Conflict Management, 18 (1), 23-40. doi:10.1108/10444060710759309, http://dx.doi.org/10.1108/10444060710759309

Komarraju, M., Dollinger, S. J., and Lovell, J. L. (2008). Individualism-collectivism in horizontal and vertical directions as predictors of conflict management styles. International Journal of Conflict Management, 19 (1), 20-35. doi:10.1108/10444060810849164, http://dx.doi.org/10.1108/10444060810849164

Lin, X. (2002). Relational contexts of conflict resolution strategies in international joint ventures: An intra-Asia case. Journal of Relationship Marketing, 1 (3/4), 23-35. doi:10.1300/J366v01n03_03, http://dx.doi.org/10.1300/J366v01n03_03

Lin, X., and Germain, R. (1998). Sustaining Satisfactory Joint Venture Relationships: The role of conflict resolution strategy. Journal of International Business Studies, 29 (1), 179-196. doi:10.1057/palgrave.jibs.8490031, http://dx.doi.org/10.1057/palgrave.jibs.8490031

$\mathrm{Lu}, \mathrm{L}-\mathrm{T}$. (2006). Conflict resolution strategy between foreign and local partners in joint ventures in China. Journal of American Academy of Business, 8 (1), 236-240.

Lu, W. J., \& Hebert, L. (2005). Equity control and the survival of international joint ventures: a contingency approach. Journal of Business Research, 58, 736-745. doi:10.1016/j.jbusres.2003.08.012, http://dx.doi.org/10.1016/j.jbusres.2003.08.012

Luo, Y. (1998). Joint venture success in China: How should we select a good partners? Journal of World Business, $\quad 33 \quad$ (2): $\quad$ 145-166. doi:10.1016/S1090-9516(99)80068-6, http://dx.doi.org/10.1016/S1090-9516(99)80068-6

Luo, Y. (2009). From gain-sharing to gain generation: The quest for distributive justice in international joint ventures. Journal of International Management, 15, 343-356. doi:10.1016/j.intman.2008.12.006, http://dx.doi.org/10.1016/j.intman.2008.12.006

Ma, Z. Lee Y., and Yu, K.-H. (2008). Ten years of conflict management studies: Themes, concepts and relationships. International Journal of Conflict Management, 19 (3), 234-248. doi:10.1108/10444060810875796, http://dx.doi.org/10.1108/10444060810875796

Madhok, A. (2006). Revisiting multinational firms' tolerance for joint ventures: a trust-based approach. Journal of International Business Studies, 37 (1), 30-43. doi:10.1057/palgrave.jibs.8400161, http://dx.doi.org/10.1057/palgrave.jibs.8400161

Makino, S. (1995). Joint Venture Ownership Structure and Performance: Japanese Joint Ventures in Asia. Doctoral dissertation, The University of Western Ontario, Canada.

Nguyen, H. L., \& Larimo, J. (2009). Foreign Parent Strategies, Control and International Joint Venture Performance. International Business Research, 2 (1), 1-13.

Nguyen, H. L., and Larimo, J. (2010). Determinants of international joint venture performance measurement: A theoretical framework. Paper presented at Academy of International Business, UK \& Ireland Chapter, Dublin $8^{\text {th }}-10^{\text {th }}$ April 2010.

O’Donnell, S. W. (2000). Managing foreign subsidiaries: agents of headquarters, or an interdependent network? Strategic Management Journal, $\quad$ 525-548. doi:10.1002/(SICI)1097-0266(200005)21:5<525::AID-SMJ104>3.0.CO;2-Q, http://dx.doi.org/10.1002/(SICI)1097-0266(200005)21:5<525::AID-SMJ104>3.0.CO;2-Q

Onishi, J., and Bliss, R. E. (2006). In search of Asia ways of managing conflict: a comparative study of Japan, Hong Kong, Thailand and Vietnam. International Journal of Conflict Management, 17 (3), 203-225. doi:10.1108/10444060610742326, http://dx.doi.org/10.1108/10444060610742326

Ozorhon, B., Arditi, D., Dikem, I., and Birgonul, T. (2008). Effect of partner fit in international construction joint ventures. Journal of Management in Engineering, 24 (1), 12-20. doi:10.1061/(ASCE)0742-597X(2008)24:1(12), http://dx.doi.org/10.1061/(ASCE)0742-597X(2008)24:1(12)

Peng, S., He, Z., and Zhu, J. (2000). Conflict management styles among employees of Sino American, Sino French, and State-owned enterprises in China. Intercultural Communication Studies, IX-2, 33-46.

Putnam, L. L., and Wilson, C. (1982). Communicative strategies in organizational conflict: reliability and 
validity of a measurement scale. In M. Burgoon (Ed.), Communication Yearbook, 6, 629-652.

Rahim, M. A. (1983). A measure of styles of handling interpersonal conflict. Academy of Management Journal, 26. 361-376. doi:10.2307/255985, http://dx.doi.org/10.2307/255985

Rahim, M. A., and Bonoma, T. V. (1979). Managing organizational conflict: a model for diagnosis and intervention. Psychological Reports, 44 (3), 1323-1344.

Ramaswamy K, Gomes L, \& Veliyath R. (1998). The performance correlates of ownership control: a study of U.S. and European MNE joint ventures in India. International Business Review, 7, 423-441. doi:10.1016/S0969-5931(98)00022-5, http://dx.doi.org/10.1016/S0969-5931(98)00022-5

Robbins, S. P. (2005). Organizational Behavior, $11^{\text {th }}$ ed. Prentice-Hall, Upper Saddle River. NJ.

Ross, D. (2009). The use of partnering as a conflict prevention method in large-scale urban project in Canada. International Journal of Managing Project Business, 2 (3), 401-418. doi:10.1108/17538370910971054, http://dx.doi.org/10.1108/17538370910971054

Saorin-Iborra, M. C. (2009). Towards an explanatory model of negotiation behavior in joint ventures. Paper presented at the $35^{\text {th }}$ EIBA Conference, $13^{\text {th }} 15^{\text {th }}$ December 2009, Valencia, Spain.

Schaan, J. L. (1983). Parent ownership and joint venture success: The case of Mexico. Doctoral dissertation, University of Western Ontario.

Shenkar, O., and Zeira, Y. (1992). Role conflicts and role ambiguity of chief executive officers in international joint ventures. Journal of international business studies, 23 (1), 55-75. doi:10.1057/palgrave.jibs.8490259, http://dx.doi.org/10.1057/palgrave.jibs.8490259

Speakman, J., and Ryals, L. (2010). A re-evaluation of conflict theory for management of multiple, simultaneous conflict episodes. International Journal of Conflict Management, 21 (2), 186-201. doi:10.1108/10444061011037404, http://dx.doi.org/10.1108/10444061011037404

Thomas, K. J. (1976). Conflict and conflict management. Chicago: Rand McNally.

Thuy, L. X., \& Quang, T. (2005). Relational capital and performance of international joint ventures in Vietnam. Asia Pacific Business Review, 11 (3), 389-410. doi:10.1080/13602380500068532, http://dx.doi.org/10.1080/13602380500068532

Wade-Benzoni, K.D., Hoffman, A.J., Thompson, L.L., Moore, D.A., Gillespie, J.J., \& Bazerman, M. H. (2002). Barriers to resolution in ideologically based negotiations: the role of calues and institutions. The Academy of Management Review, 27 (1), 41-57.

Wang, C. L., Lin, X., Chan, A. K. K., and Shi, Y. (2005). Conflict handling styles in international joint ventures: Across cultural and cross national comparison. Management International Review, 45 (1), 3-21.

White III, O. G., Joplin, J. R.W., and Salama, M. F. (2007). Contracts and conflict resolution strategies in foreign ventures: a transaction cost perspective. International Journal of Conflict Management, 18 (4), 376-389. doi:10.1108/10444060710833478, http://dx.doi.org/10.1108/10444060710833478

Wilson, J., and Brennan, R. (2009). Relational factors in UK-Chinese international joint ventures, European Business Review, 21 (2), 159-171. doi:10.1108/09555340910940150, http://dx.doi.org/10.1108/09555340910940150

Yan, A., and Duan, J. (2003). Interpartner fit and its performance implications: A four case study of US-China joint ventures. Asia Pacific Journal of Management, 20 (4), 541-564. doi:10.1023/A:1026399211360, http://dx.doi.org/10.1023/A:1026399211360

Yavas, U, Eroglu, D., and Eroglu, S. (1994). Sources and management of conflict: The case of Saudi-US joint ventures. Journal of International Marketing, 2 (3), 61-82. 
Table 1. Conflict resolution strategies and their applicability

\begin{tabular}{|c|c|c|c|c|c|c|}
\hline Strategy & $\begin{array}{l}\text { Problem-solvi } \\
\text { ng strategy }\end{array}$ & $\begin{array}{l}\text { Compromising } \\
\text { strategy }\end{array}$ & $\begin{array}{l}\text { Forcing } \\
\text { Strategy }\end{array}$ & $\begin{array}{l}\text { Legalistic } \\
\text { strategy }\end{array}$ & $\begin{array}{l}\text { Avoiding } \\
\text { Strategy }\end{array}$ & $\begin{array}{l}\text { Accommodating } \\
\text { strategy }\end{array}$ \\
\hline Features & $\begin{array}{l}\text { Concerning for } \\
\text { own and other's } \\
\text { benefits }\end{array}$ & $\begin{array}{l}\text { Acceptance of } \\
\text { reducing one } \\
\text { own benefits }\end{array}$ & $\begin{array}{l}\text { Maximize } \\
\text { one own } \\
\text { benefits }\end{array}$ & $\begin{array}{l}\text { Protect one } \\
\text { own } \\
\text { benefits } \\
\text { with legal } \\
\text { action }\end{array}$ & $\begin{array}{l}\text { Delaying } \\
\text { to solve the } \\
\text { conflict }\end{array}$ & $\begin{array}{l}\text { Making } \\
\text { concession on } \\
\text { one own } \\
\text { benefits }\end{array}$ \\
\hline \multicolumn{7}{|l|}{ Applicability } \\
\hline Time factor & No pressure & Great pressure & $\begin{array}{l}\text { Great } \\
\text { pressure }\end{array}$ & $\begin{array}{l}\text { No } \\
\text { pressure }\end{array}$ & $\begin{array}{l}\text { No } \\
\text { pressure }\end{array}$ & Great pressure \\
\hline $\begin{array}{l}\text { Importance of } \\
\text { the issue }\end{array}$ & Important & Important & Important & Important & $\begin{array}{l}\text { Not so } \\
\text { important }\end{array}$ & Not important \\
\hline $\begin{array}{l}\text { Important of } \\
\text { relationship }\end{array}$ & Important & Important & $\begin{array}{l}\text { Not } \\
\text { important }\end{array}$ & Not so important & Important & Very important \\
\hline & $\begin{array}{l}\text { Not so } \\
\text { relevant }\end{array}$ & Equal power & & Dominated & $\begin{array}{l}\text { Equal or } \\
\text { dominated }\end{array}$ & Dominated \\
\hline Advantages & $\begin{array}{l}\text { Maintain } \\
\text { both parties' } \\
\text { benefits } \\
\text { Fostering } \\
\text { mutual respect } \\
\text { and rapport }\end{array}$ & $\begin{array}{l}\text { Promoting } \\
\text { fairness }\end{array}$ & $\begin{array}{l}\text { Quickly } \\
\text { solved } \\
\text { problems }\end{array}$ & $\begin{array}{l}\text { Protection } \\
\text { minority } \\
\text { partners }\end{array}$ & 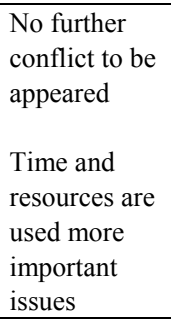 & $\begin{array}{l}\text { Quick resolve } \\
\text { conflict } \\
\text { Keeping } \\
\text { partners happy }\end{array}$ \\
\hline Disadvantages & $\begin{array}{l}\text { Time and } \\
\text { resource } \\
\text { consuming }\end{array}$ & $\begin{array}{l}\text { Willingness to } \\
\text { scarify some } \\
\text { of the benefits } \\
\text { from the other } \\
\text { partners }\end{array}$ & $\begin{array}{l}\text { Partner } \\
\text { relationsh } \\
\text { ip may be } \\
\text { damaged }\end{array}$ & $\begin{array}{l}\text { Expensive } \\
\text { method } \\
\text { Partner } \\
\text { relationshi } \\
\text { p may also } \\
\text { be } \\
\text { damaged }\end{array}$ & $\begin{array}{l}\text { The } \\
\text { problem } \\
\text { will not } \\
\text { disappear } \\
\text { by itself }\end{array}$ & $\begin{array}{l}\text { Scarifying own } \\
\text { benefits }\end{array}$ \\
\hline
\end{tabular}

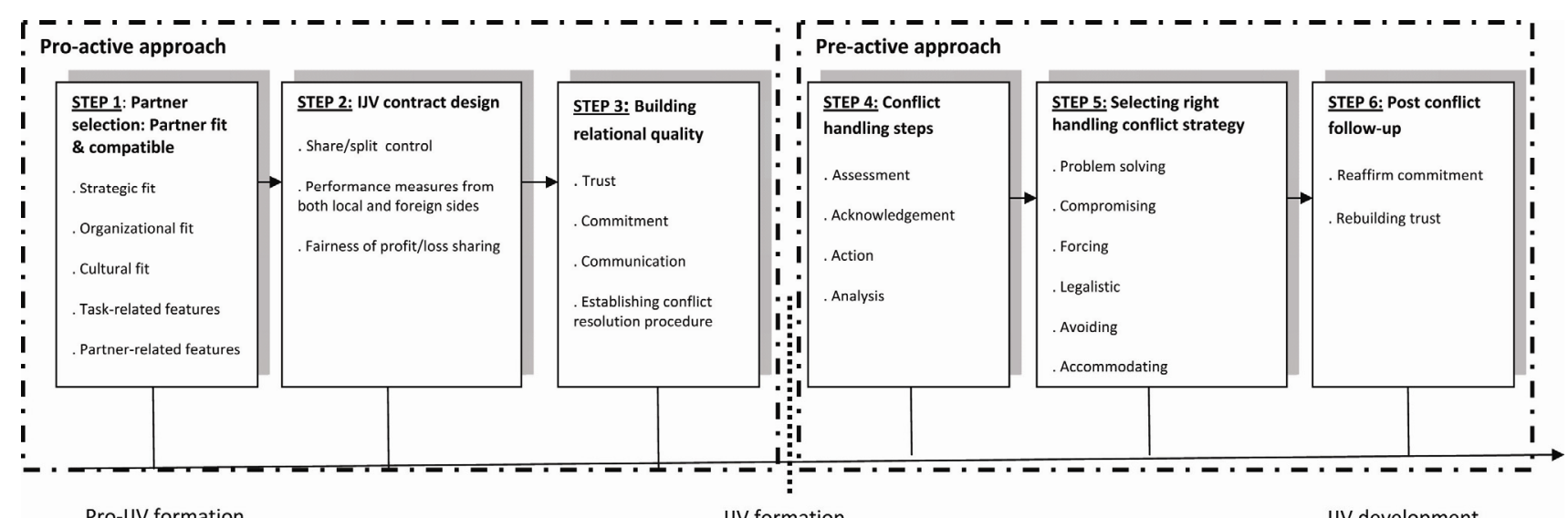

Pro-IJV formation

Figure 1. Conflict management in international joint ventures 